\title{
Perancangan Penyalaan Engine Sepeda Motor Berbasis Arduino Melalui Bluetooth Android
}

\author{
Andika Jamal, Muhammad Ridha Fauzi * \\ Program Studi Mesin Otomotif, Fakultas Teknik, Universitas Muhammadiyah Riau \\ Jl. Tuanku Tambusai Ujung No. 1 Pekanbaru \\ *E-mail: mridhafauzi@umri.ac.id
}

\begin{abstract}
Motorcycle ignition which also functions as a motorcycle safety needs to be designed and made as safe as possible to avoid the loss of the vehicle from theft cases. This equipment is designed to turn on/off and search for motorcycles using a remote from a smartphone with an android operating system via a bluetooth network. The bluetooth input is controlled using the Arduino Uno microcontroller. From the test results, it is found that the maximum distance that can be achieved between Android and Bluetooth to operate a motorcycle engine is about 10 meters. This system also makes our motorcycle engine ignition a smart ignition.
\end{abstract}

Keywords: security, arduino uno, android, bluetooth

\begin{abstract}
Abstrak
Penyalaan sepeda motor yang sekaligus juga berfungsi sebagai pengaman sepeda motor perlu dirancang dan dibuat seaman mungkin untuk menghindari hilangnya kendaraan dari kasus pencurian. Peralatan yang dirancang ini untuk menghidupkan/mematikan dan mencari sepeda motor menggunakan remote dari smartphone dengan sistem operasi android melalui jaringan bluetooth. Input bluetooth dikontrol menggunakan mikrokontroler Arduino Uno. Dari hasil pengujian diperoleh bahwa jarak maksimum yang dapat dicapai antara android dengan Bluetooth untuk mengoperasikan engine sepeda motor adalah sekitar 10 meter. Sistem ini juga membuat penyalaan engine sepeda motor kita menjadi penyalaan pintar.
\end{abstract}

Kata kunci: pengaman, arduino uno, android, bluetooth 


\section{Pendahuluan}

Zaman yang semakin maju melahirkan berbagai solusi untuk memecahkan permasalahan manusia. Keadaan ini semakin mendorong manusia untuk terus melakukan berbagai macam percobaan dan belajar sehingga dapat memberikan keuntungan lebih untuk membantu manusia dalam menjalakan aktivitasnya seharihari. Salah satunya adalah smartphone. Selain itu, sensor dan komponen elektronik yang berkembang pesat saat ini adalah pengendali mikro single-board.

Android merupakan salah satu keluarga Linux sehingga memungkinkan setiap orang dapat mengembangkan sistem Android itu sendiri. Saat ini, Google telah meluncurkan software khusus yang dapat melakukan perkembangan terhadap sistem operasi android.

Tharishny, dkk [1] Massachusetts Institut Teknologi App Inventor mengembangkan alat pemrograman yang dapat digunakan untuk membuat desain aplikasi dan program pada aplikasi untuk perangkat Android dengan drag and drop perintah yang sudah disediakan.

Tool tersebut dapat digunakan dalam merancang mikrokontroler. Mikrokontroler merupakan suatu alat pengendali yang memiliki ukuran kecil, yang dapat dioperasikan bersamaan dengan alat elektronik lainnya. Keunggulan yang dimiliki mikrokontroler yaitu dapat digunakan sebagai suatu sistem kendali, selain itu terdapat banyak pengendali mikro single board yang tidak berbasis open-source sehingga sulit untuk membuat sistem pengendali.

Bluetooth merupakan alat yang banyak digunakan untuk perangkat elektronik yang digunakan untuk berkomunikasi. Bluetooth memiliki dua perangkat yaitu pengirim data (master) dan penerima (slave). Bluetooth $\mathrm{HC}-05$ merupakan serial port protocol digunakan sebagai alat komunikasi tanpa menggunakan kabel (wireless). HC-05 menggunakan input besaran antara 4,6-6,0V dan TX RX digunakan untuk komunikasi dengan Bluetooth yang lain.

Perancangan penyalaan sepeda motor telah dilakukan oleh beberapa peneliti sebelumnya di antaranya Jufriyanto [2] telah merancang penyalaan atau sistem starter menggunakan sidik jari berbasis Arduino Uno Atmega 328. Dimana jika jari ditap pada sensor finger print untuk kali pertama dan jari dikenali maka sistem kelistrikan sepeda motor akan on dan jika ditap kali kedua maka relay juga akan on dengan lampu indicator on maka engine sepeda motor akan on pula.

Yudi Afriyan [3] juga telah melakukan perancangan pengaman dan penyalaan sepeda motor menggunakan RFID berbasis Arduino. Pengaman sepeda motor ini diprogram dengan pengaman starter kendaraan memakai Card/Tag yang telah terpasang di kendaraan tanpa takut kendaraan dapat dibobol dan di-starter melalui kunci kontak. Sepeda motor tidak dapat dihidupkan kecuali dengan menginput/mentapping Card/Tag yang benar yang sudah diprogram melalui Arduino.

Selanjutnya Erlian Renalda Permana [4] meneliti sistem keamanan sepeda motor berbasis arduino dan module GPS (Global Positioning Sistem). Dalam penelitian ini telah dirancang sebuah sistem yang berfungsi untuk mengetahui lokasi dan memonitor keberadaan sebuah kendaraan. Sistem ini bekerja menggunakan lingkup jaringan. Untuk mengetahui lokasi kendaraan dilakukan dengan cara mengirim SMS koordinat lokasi ke ponsel yang terhubung dengan sistem ini.

Dari beberapa penelitian yang terdahulu maka di sini penulis merancang penyalaan engine sepeda motor menggunakan module Bluetooth sebagai inputnya untuk keamanan dan penyalaan pintar pada sepeda motor dengan menggunakan smartphone sebagai kunci kontaknya. Aplikasi yang digunakan berbasis android yang dibuat melalui App Inventor, Bluetooth digunakan sebagai media transmisi dan terima data secara wireless antara aplikasi remote dengan perangkat kontrol. Dalam penelitian yang berjudul Android Pengontrol Mini Sauna untuk Hewan Menggunakan Arduino Uno oleh Taufiq [5] mengatakan bahwa jarak maksimal Bluetooth HC-05 adalah sejauh 10 meter. Sehingga mempunyai batasan jarak antara perangkat android dengan sepeda motor.

Tujuan dari penelitian ini adalah merancang sistem penyalaan engine menggunakan smatphone tanpa memggunakan kunci yang diterapkan pada sepeda motor dan menjadikan sepeda motor lebih aman dari pencurian.

Sistem ini memiliki prinsip kerja yang sama dengan kunci konvensional sepeda motor pada umumnya. Sistem ini menggunakan remote berupa smartphone dengan sistem operasi android melalui jaringan bluetooth. Ketika sepeda motor diparkirkan di tempat yang ramai dapat dicari dengan mudah dengan menyalakan alarm.

Karena engine sepeda motor dikendalikan oleh smartphone, dimana untuk menyalakan engine harus memasukan sandi dari modul Bluetooth alat ini. Sistem ini juga membuat penyalaan engine sepeda motor kita menjadi 
penyalaan pintar, bisa kita kendalikan dari radius 10 meter.

\section{Methodologi}

\subsection{Waktu dan Tempat}

Penelitian ini telah dilakukan dari bulan Januari sampai dengan bulan Maret 2021 di laboratorium Program Studi Mesin Otomotif Fakultas Teknik Universitas Muhammadiyah Riau dan di Workshop Aslamtech, Pekanbaru.

\subsection{Alat dan Bahan}

Alat yang digunakan dalam penelitian ini adalah solder, obeng, multitester, isolasi kabel, gunting dan tang lancip.

Sedangkan bahan yang digunakan dalam penelitian ini adalah sepeda motor Honda Kharisma, Arduino Uno, relay $5 \mathrm{~V}$, Module Bluetooth HC-05, Converter dc, timah, kabel.

\subsection{Rancangan Sistem Penyalaan}

Pada Gambar 1 dapat dilihat diagram sistem penyalaan dengan bluetooth. Cara kerja dari system penyalaan engine sepeda motor berbsis arduino dengan module Bluetooth adalah menjadikan smartphone sebagai kunci kontak yang dapat mengatur status engine, start engine, dan alarm . Selanjutnya letak dari masing-masing komponen sistem penyalaan berbasis arduino dengan module Bluetoothdapat dilihat pada Gambar 2. Module Bluetooth terletak pada speedometer untuk melihat lampu indikator pada module Bluetooth. Selain itu speedometer merupakan tempat tertutup dan tinggi pada sepeda motor sehingga komponen aman dari tetesan air. Sedangkan arduino dan module relay terletak pada ruang bagasi sepeda motor karena komponen ini membutuhkan ruang yang cukup besar dan bagasi sepeda motor merupakan tempat yang aman dari air, dimana komponen sistem penyalaan ini ialah komponen yang sangat sensitif terhadap air.

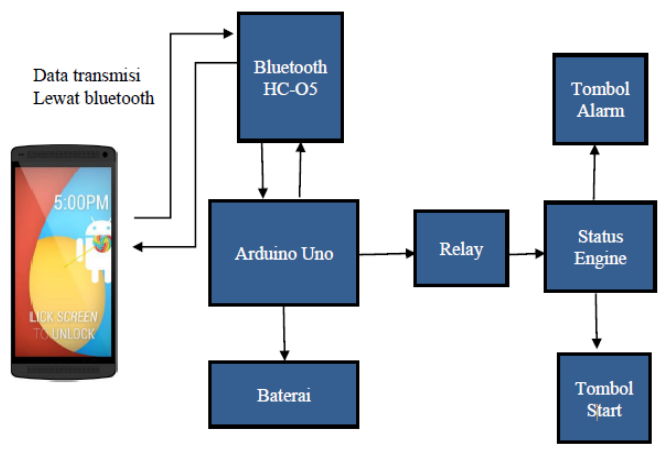

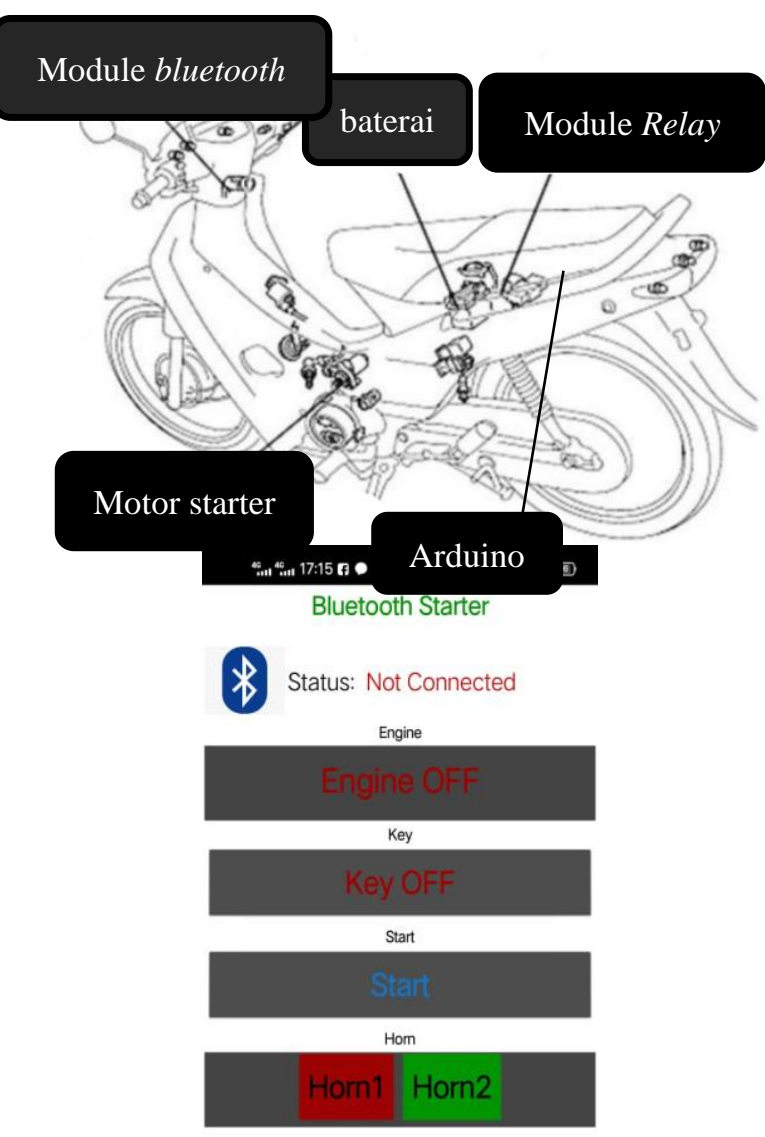

Gambar 2. Letak rancangan alat pada sepeda motor

Dari Gambar 1 dan 2 dapat dilihat bahwa sistem penyalaan engine sepeda motor melalui Bluetooth tersebut menggunakan 4 komponen utama yaitu arduino, module Relay, module Bluetooth, dan converter dc. Arduino sebagai otak system yang menerima signal input dari module Bluetooth dan output-nya mengaktifkan Relay. Fungsi masing- masing komponen :

1. Converder DC (LM2596 DC-DC HW-

411)

Converter dc ini berfungsi sebagai alat untuk penurun tegangan, karena tegangan kerja dari arduino 5V dan kita mengambil tegangan dari baterai motor yang dimana tegangan motor $12 \mathrm{~V}$. Oleh sebab itu alat ini digunakan untuk menjaga kestabilan tegangan kerja dari arduino .

2. Arduino

Arduino berfungsi sebagai otak atau komponen inti dari sistem penyalaan ini, karena semua perintah dari alat ini diatur 
pada Arduino. Arduino berkerja setelah mendapatkan signal input dari Bluetooth .

3. Modul Bluetooth $\mathrm{HC}-05$

Modul Bluetooth HC-05 berfungsi untuk menangkap signal dari android dan mengirim signal ke Arduino . Modul Bluetooth hanya dapat menerima signal dalam radius kurang lebih 10 meter.

4. Relay

Relay berfungsi sebagai pemutus dan penghubung arus listrik di sepeda motor. Relay ini dijadikan sebagai output arduino dan bekerja ketika arduino mendapat signal input dari modul Bluetooth hc-05.

\subsection{Perancangan Alat}

Skema rancangan alat dapat dilihat pada Gambar 3. Pada saat Bluetooth android dihubngkan dengan Bluetooth module HC-05 pada arduino, Bluetooth module akan menerima autentikasi dari android. Dengan ini Android dapat melakukan perintah turn on status engine, turn on alarm, turn on engine.

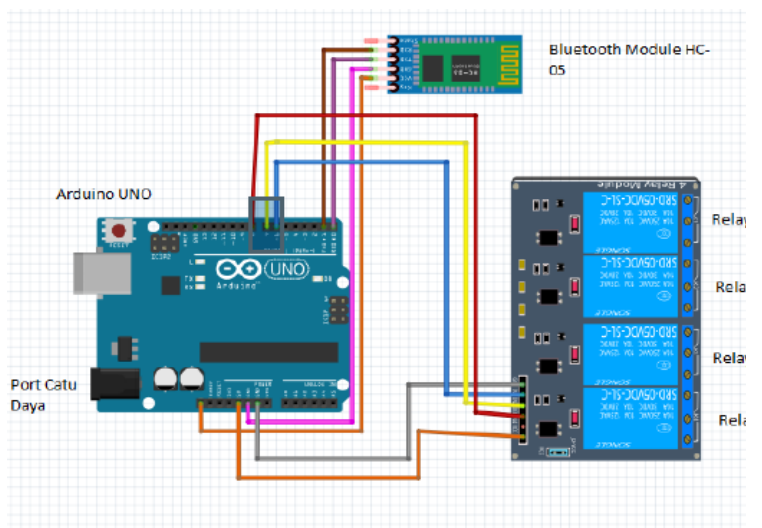

Gambar 3. Skema rancangan alat

Sistem penyalaan ini diimplementasikan pada sepeda motor dan ponsel android. Aplikasi ini dapat bekerja pada android versi Jelly Bean, Lollipop, Marshmallow, dan lainnya ,dengan aplikasi Bluetooth. Penggunaan sistem ini dapat membantu user dalam menyalakan engine sepeda motor dari jarak tertentu.

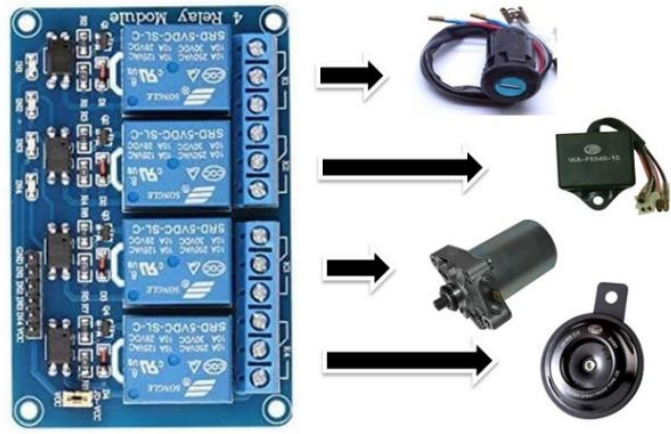

Gambar 4. Sambungan Output Relay

Berdasarkan Gambar 4 di atas dapat dijelaskan fungsi dari masing - masing Relay, yaitu :

1. Relay 1( key) sebagai saklar penghubung dan pemutus arus dari battray ke aksesoris pada sepeda motor seperti lampu, klakson ,dan lainnya.

2. Relay 2(status engine) sebagai saklar penghubung dan pemutus arus (+) cdi pada sepeda motor.

3. Relay 3 (starter)sebagai saklar penghubung dan pemutus arus (+) starter pada sepeda motor.

4. Relay 4 (horn) sebagai penghubung dan pemutus arus ke klakson pada sepeda motor, ini dijadikan sebagai alarm di sepeda motor.

\subsection{Perakitan Alat}

Dalam perakitan alat ini ada beberapa langkah pengerjaan di antaranya:

1. Merangkai module Bluetooth dengan Arduino Uno.

Pada Gambar 5 dapat dilihat bahwa Modul Bluetooth disambungkan ke Arduino uno dengan cara :

- Pin VCC yang ada di modul Bluetooth HC-05 disambungkan ke pin VCC Arduino uno

- Pin GND yang ada di modul Bluetooth HC-05 disambungkan ke pin GND Arduino uno

- Pin RXD yang ada di modul Bluetooth HC-05 disambungkan ke pin TXD Arduino uno

- Pin TXD yang ada di modul Bluetooth HC-05 disambungkan ke pin RXD Arduino uno 


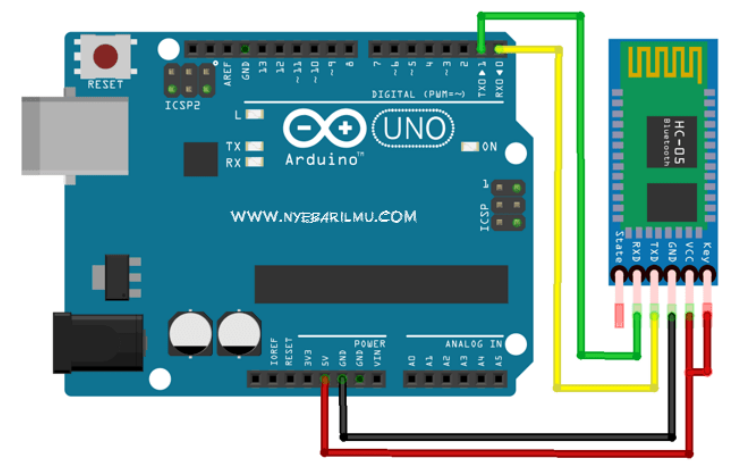

Gambar 5. Rangkaian Bluetooth HC-05 dan Arduino Uno

2. Merangkai Arduino Uno dengan module Relay

Di Gambar 6 dapat dilihat sambungan antara arduino uno dengan module Relay dengan cara :

- $\quad$ VCC dihubungkan ke 5V (pin yang terdapat di arduino)

- IN4 / Relay4 dihubungkan ke pin 5 arduino uno

- IN3 / Relay3 dihubungkan ke pin 4 arduino uno

- IN2 / Relay2 dihubungkan ke pin 3 arduino uno

- IN1 / Relay1 dihubungkan ke pin 2 arduino uno

- GND modul Relay dihubungkan ke GND di arduino uno

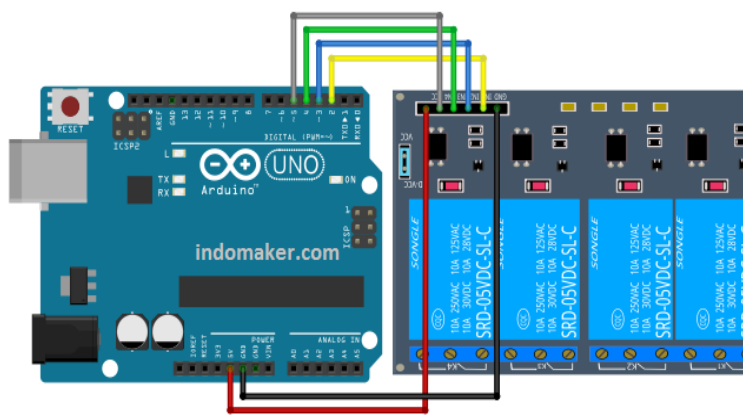

Gambar 6. Rangkaian Modul Relay ke Arduino Uno

3. Merangkai Converter DC dengan Arduino Uno

Untuk merangkai kedua komponen ini, dilakukan dengan cara :

- Menghubungkan (+) output converter dc dengan $(+)$ port catu daya arduino uno.

- Menghubungkan (-) output converter dc dengan (-) port catu daya arduino uno.
- Sedangkan (+) dan (-) input converter dc di baterai sepeda motor.

\section{Memprogram Arduino Uno}

Langkah - langkah memprogram arduino uno adalah sebagai berikut :

1. Membuat sketch program module Bluetooth

2. Mengetik kode program module Bluetooth pada sketch

3. Menyimpan sketch program module Bluetooth

4. Menjalankan sketch program module Bluetooth

5. Mengupload file program yang telah dibuat ke arduino

\section{Hasil dan Pembahasan}

Hasil rangkaian sistem penyalaan engine sepeda motor dapat dilihat pada Gambar 7 yang terdiri dari input (module Bluetooth), proses (arduino), dan output (module Relay).

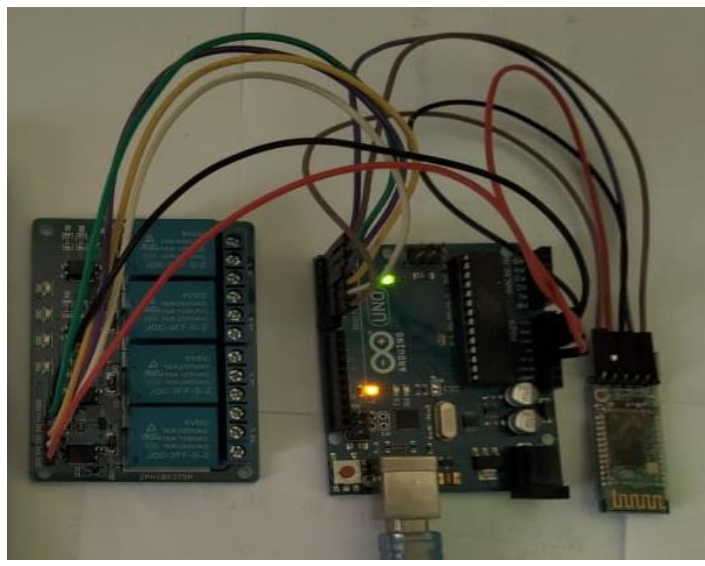

Gambar 7. Sistem penyalaan engine sepeda motor

Komponen input dari system ini adalah module Bluetooth yang berfungsi untuk menangkap signal dari android sebagai remote control. Android akan memberikan signal ke module Bluetooth lalu diteruskan ke Arduino (proses). Pada Arduino yang telah diupload sketch program, Arduino akan mengontrol kerja dari output. Output berupa Relay yang berfungsi sebagai saklar digital mengubah sinyal analog menjadi sinyal digital. Rangkaian Proses berupa Arduino berfungsi sebagai perintah/pengontrol komponen lainnya. Alat ini menggunakan Relay 4 channel, Relay pertama dijadikan sebagai kunci kontak atau saklar aksesoris pada sepeda motor (lampu, klakson, dan lainnya), Relay kedua dihubungkan ke CDI sepeda motor, Relay ketiga

SURYA TEKNIKA Vol. 8 No. 1, Juni 2021: 265-273 
dihubungkan ke motor starter, dan Relay keempat dihubungkan ke klakson sebagai alarm pada sepeda motor.

\subsection{Pengujian DC Converter}

Hasil pengujian DC Converter dapat dilihat pada Tabel 1 di bawah ini.

Tabel 1. Pengukuran Tegangan DC Converter

\begin{tabular}{cc}
\hline $\begin{array}{c}\text { Tegangan Input } \\
(\mathrm{Vdc})\end{array}$ & $\begin{array}{c}\text { Tegangan Output } \\
(\mathrm{Vdc})\end{array}$ \\
\hline 12 & 5 \\
\hline
\end{tabular}

Dari hasil pengujian baterai, sumber arus dengan tegangan $12 \mathrm{Vdc}$ diturunkan dari $12 \mathrm{Vdc}$ menjadi $5 \mathrm{Vdc}$ menggunakan DC Converter sehingga tegangan yang masuk ke dalam Arduino sebesar $5 \mathrm{Vdc}$ dan Arduino pun menerima tegangan yang cukup dan tidak berlebih.

\subsection{Pengujian Konektivitas Module Bluetooth dengan Android}

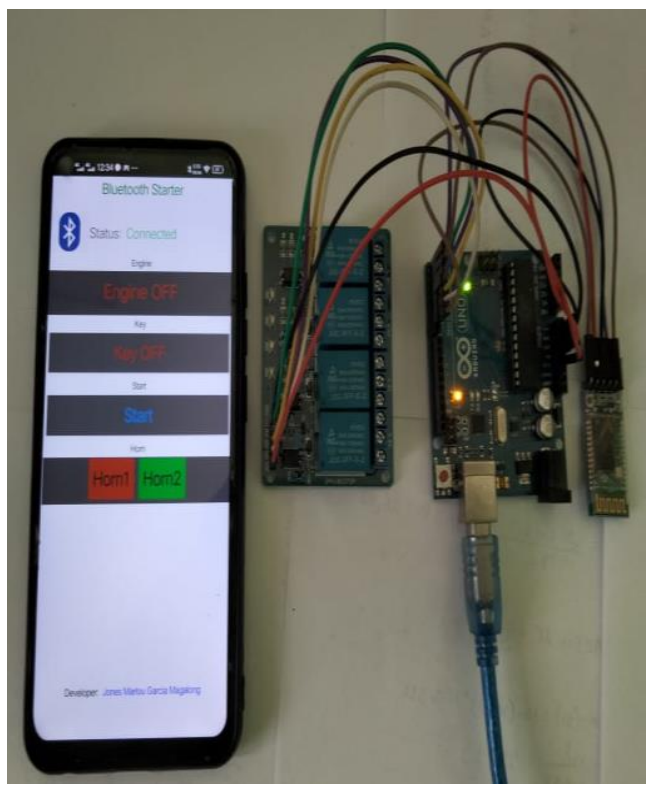

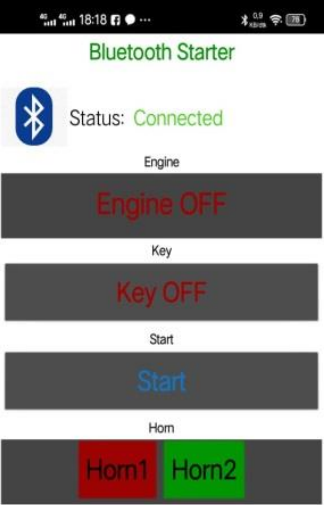

Gambar 8. Konektivitas Module Bluetooth Dengan Android

Pada Gambar 8 dapat dilihat konektivitas antara module Bluetooth dengan android yang terhubung dengan baik tanpa masalah. Pengujian ini dilakukan dengan mengaktifkan panel Bluetooth pada android sehingga IP dari module Bluetooth android terdeteksi. sambungkan android dengan IP dari Bluetooth dengan memasukkan kata sandi dari module Bluetooth. Setelah itu masuk ke dalam aplikasi Bluetooth Starter dan klik logo Bluetooth yang ada pada sudut kiri atas aplikasi. Di dalamnya terdapat IP module Bluetooth, lalu dengan mengklik IP dan menunggu beberapa detik maka android terkoneksi dengan module Bluetooth. Untuk mengetahui android berhasil terkoneksi dengan module Bluetooth dapat dilihat dari status aplikasi muncul informasi "Connected".

\subsection{Pengujian Module Relay}

Pada pengujian module Relay, terdapat 2 pengujian yaitu :

3.3.1. Pengujian Tegangan Input Module Relay

Hasil pengujian tegangan input Relay ditampilkan pada Tabel 2 berikut ini :

Tabel 2. Pengukuran Tegangan Input Relay

\begin{tabular}{|c|c|}
\hline Titik Pengujian & Tegangan Input (V) \\
\hline Relay 1 (Kunci Kontak) & 5 \\
\hline Relay 2 ( cdi) & 5 \\
\hline Relay 3 ( Starter ) & 5 \\
\hline Relay 4 ( Horn ) & 5 \\
\hline
\end{tabular}

Input Relay memerlukan tegangan sebesar 5 Volt untuk mengaktifkan koil dan keluaran pada Arduino sebesar 4,8 Volt sebagai trigger untuk saklar otomatis.

\subsubsection{Pengujian Konektivitas Module Relay}

Pengujian konektivitas module Relay dengan android dapat dilihat pada Gambar 9 - Gambar 13 dan Tabel 3 di bawah ini: 


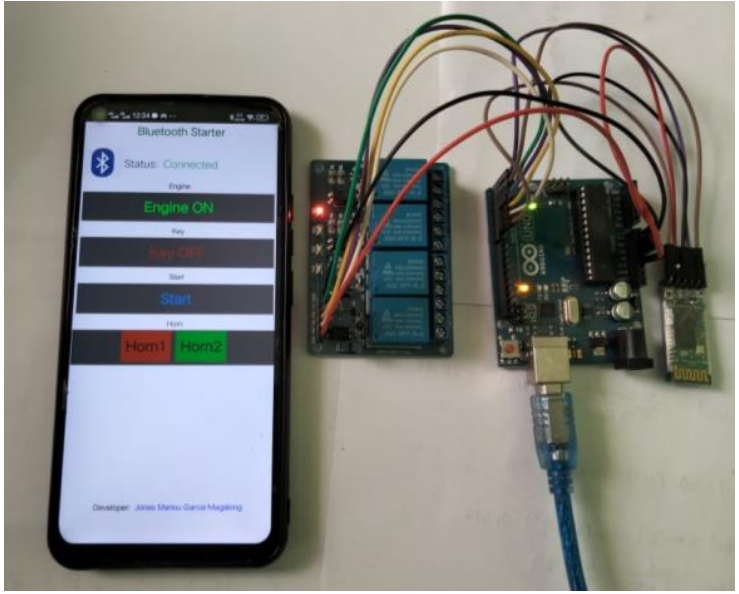

Gambar 9. Pengujian Relay 1 (CDI)

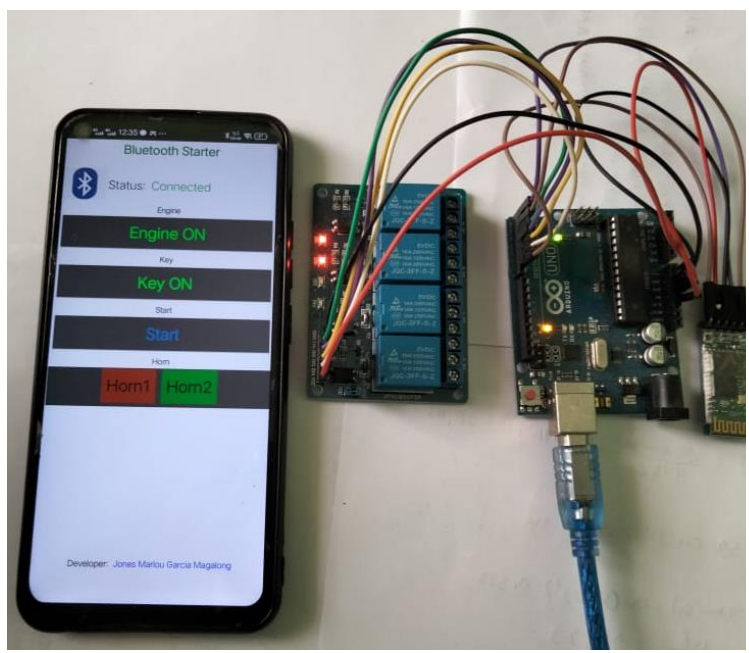

Gambar 10. Pengujian Relay 2 (Key)

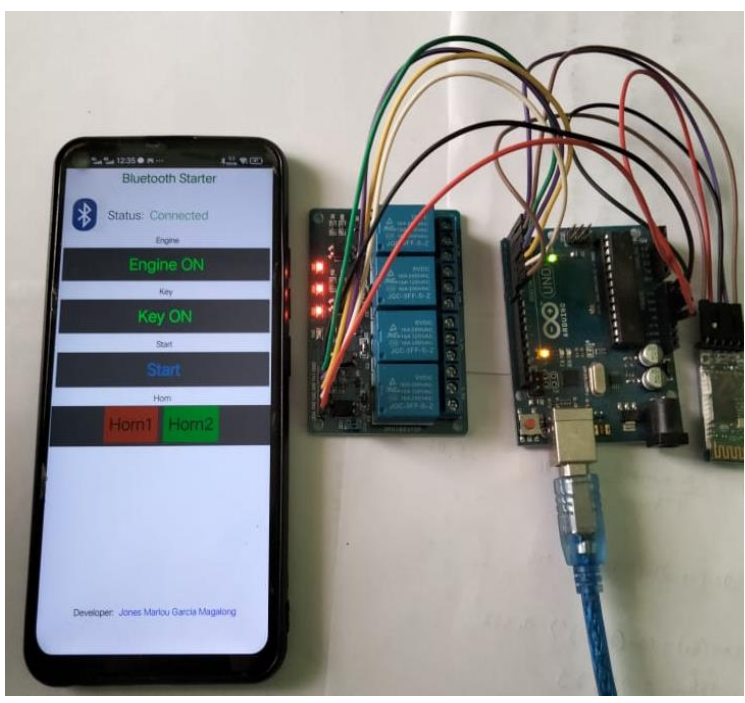

Gambar 11. Pengujian Relay 3 (Starter)

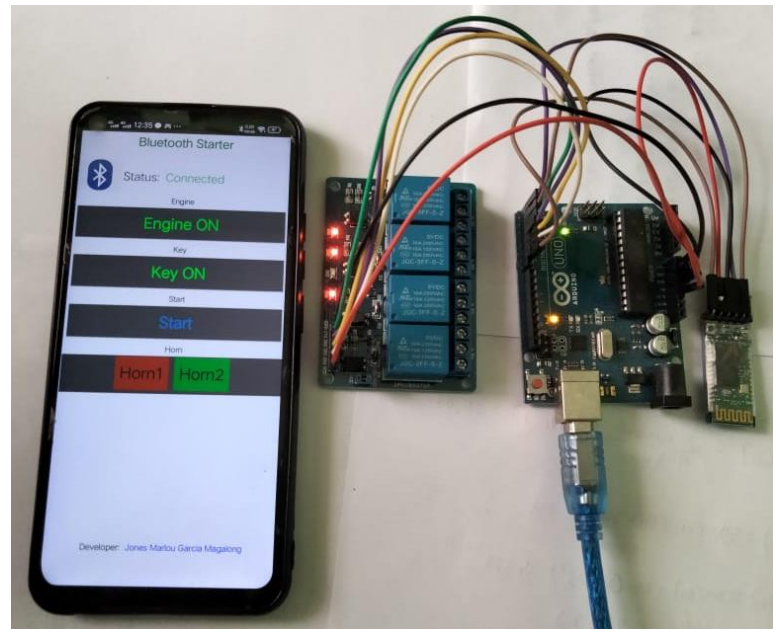

Gambar 12. Pengujian Relay 4 (Horn/Alarm)

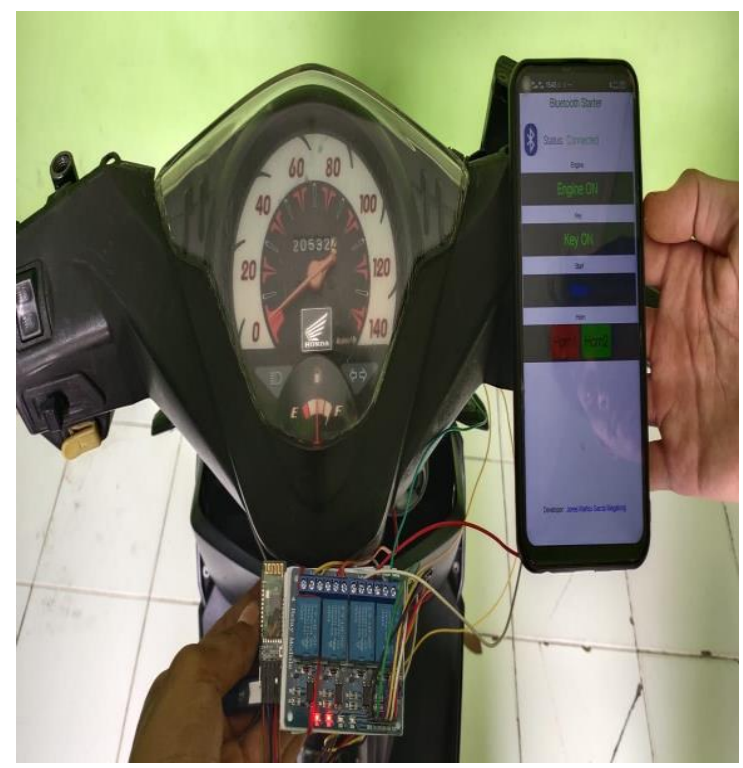

Gambar 13. Pengujian Alat Pada Sepeda Motor

Tabel 3. Hasil Pengujian Relay

\begin{tabular}{ccccl}
\hline $\begin{array}{c}\text { Relay } \\
1\end{array}$ & $\begin{array}{c}\text { Relay } \\
2\end{array}$ & $\begin{array}{c}\text { Relay } \\
3\end{array}$ & $\begin{array}{c}\text { Relay } \\
4\end{array}$ & \multicolumn{1}{c}{ Keterangan } \\
\hline & & & & $\begin{array}{l}\text { Ketika Relay } 1 \\
\text { bernilai 1\& }\end{array}$ \\
1 & 0 & 0 & 0 & $\begin{array}{l}\text { Relay 2, 3 dan 4 } \\
\text { bernilai 0 maka } \\
\text { kunci kontak } \\
\text { "ON". }\end{array}$ \\
\hline & & & $\begin{array}{l}\text { Ketika Relay } \\
\text { 1dan 2 bernilai 1 } \\
\text { dan Relay 3, 4 } \\
\text { bernilai 0 maka } \\
\text { kunci kontak } \\
\text { "ON" dan arus } \\
\text { (+) pada CDI } \\
\text { terhubung, tetapi } \\
\text { motor starter }\end{array}$ \\
\hline & & &
\end{tabular}

SURYA TEKNIKA Vol. 8 No. 1, Juni 2021: 265-273 


\begin{tabular}{|c|c|c|c|c|}
\hline & & & & $\begin{array}{l}\text { sepeda motor } \\
\text { belum bisa } \\
\text { diaktifkan. }\end{array}$ \\
\hline 1 & 1 & 1 & 0 & $\begin{array}{l}\text { Ketika Relay } 3 \text { di } \\
\text { aktifkan (bernilai } \\
\text { 1), maka Relay } 1 \\
\text { dan } 2 \text { secara } \\
\text { otomatis aktif } \\
\text { (bernilai } 1 \text { ), } \\
\text { pada tahap ini } \\
\text { motor starter } \\
\text { akan aktif } \\
\text { selama } 3 \text { detik, } \\
\text { dan Relay } 3 \\
\text { "OFF" kembali } \\
\text { (bernilai 0). }\end{array}$ \\
\hline 0 & 0 & 0 & 1 & $\begin{array}{l}\text { Ketika Relay } 4 \\
\text { bernilai } 1 \text {, maka } \\
\text { sepeda motor } \\
\text { memberikan } \\
\text { notifikasi berupa } \\
\text { bunyi horn } \\
\text { selama } 4 \text { detik } \\
\text { ini sekalian } \\
\text { berfungsi sebagai } \\
\text { alarm jika } \\
\text { memarkirkan } \\
\text { sepeda motor di } \\
\text { area yang ramai. }\end{array}$ \\
\hline
\end{tabular}

Dari Tabel 3 di atas dapat dilihat bahwa jika kondisi Relay 1 bernilai 1, maka arus mengalir ke Relay dan kunci kontak "ON", dan jika Relay 2 bernilai 1, maka arus mengalir ke Relay sehingga arus (+) pada CDI akan terhubung. Namun jika Relay3 bernilai 1 maka motor starter pada sepeda motor aktif selama 3 detik, di saat yang bersamaan pula Relay 1 dan 2 aktif secara otomatis. Pada tahap ini Sepeda motor menyala (Relay 3 bernilai 1) dan mati ketika bernilai 0 . Jika Relay 4 yang bernilai 1, maka sepeda motor memberikan notifikasi berupa bunyi horn 4 detik yang berfungsi untuk mengetahui letak dari sepeda motor saat parkir dalam keadaan kendaraan ramai

\subsection{Pengujian Jarak Module Bluetooth}

Pengujian jarak ini bertujuan untuk mengetahui radius maksimum yang dapat dicapai dari alat penyalaan engine sepeda motor untuk dapat dikendalikan oleh smartphone. Hasil pengujian jarak Bluetooth ini dapat dilihat pada Tabel 4 berikut :

Tabel 4. Hasil Pengujian Jarak Module Bluetooth

\begin{tabular}{ccc}
\hline No & Jarak & Hasil \\
\hline 1 & 0 meter & Ok
\end{tabular}

\begin{tabular}{rrl}
2 & 2 meter & Ok \\
3 & 4 meter & Ok \\
4 & 6 Meter & Ok \\
5 & 8 meter & Ok \\
6 & 10 meter & Ok \\
7 & 12 meter & No \\
8 & 14 meter & No \\
9 & 16 meter & No \\
\hline
\end{tabular}

Dari Tabel 4 di atas bisa dilihat hasil pengujian jarak kerja antara android dengan module Bluetooth. Hasil "Ok" bermakna antara android dan module Bluetooth terkoneksi dan dapat memberi dan menerima signal antara keduanya. Sedangkan untuk hasil "No" merupakan jarak di luar batas koneksi alat. Ini berarti bahwa alat dapat bekerja pada radius 10 meter melalui smartphone (android) sebagai remote controlnya.

\section{Simpulan}

Penelitian Penyalaan Engine Sepeda Motor Berbasis Arduino Melaui Bluetooth Android telah berhasil dilaksanakan. Setelah dilakukan pengujian, maka jarak maksimum yang dapat dicapai antara android dengan Bluetooth sekitar 10 meter. Untuk dapat terhubung dengan alat kita harus mengubungkan Bluetooth di smartphone dengan module Bluetooth pada alat dengan cara menginputkan password atau kata sandi. Bila password atau kata sandi salah maka alat di pastikan tidak akan bisa di kendalikan. Adapaun hal hal yang dapat kita kendalikan di dalam smartphone pada sepeda motor ialah, on/off nya kunci kontak, menghubung dan memutuskan arus pengapian khususnya pada CDI sepeda motor, menyalakan starter sepeda motor, dan alarm untuk mengetahui letak posisi dari sepeda motor dalam keadaan ramai.

\section{Daftar Pustaka}

[1] Tharishny, S., Selvan, S., \& Nair, P. (2016). Android based Smart House Control via Wireless Communication. International Journal of Scientific Engineering and Technology, (5), 323-325.

[2] Jufriyanto, Reza Nandika (2019). Perancangan Sistem Starter Sepeda Motor 
Menggunakan Sidik Jari Berbasis Arduino Uno Atmega 328. Jurnal Sigma Teknika 2 (2), 173-178

[3] Yudhi Afriyan, Fauzi, M. R (2020). Rancang Bangun Pengaman Sepeda Motor Menggunakan RFID Berbasis Arduino. Jurnal Surya teknika, 7(2), 164-171.

[4] Permana, E., R. Rancang Bangun Sistem
Keamanan Sepeda Motor Berbasis Arduino dan GPS (Global Positioning System). Tugas Akhir. STIKOM Surabaya.2018.

[5] Taufiq, V. L. F. (2016). Android controlled mini sauna for animal laboratory research facility using arduino uno. 